\title{
Antifungal Activity of Pseudomonas frederiksbergensis CMAA 1323 Isolated from the Antarctic Hair Grass Deschampsia antarctica
}

\author{
Itamar S. Melo $^{{ }^{\star}}$, Wallace R. Souza ${ }^{1}$, Leonardo J. Silva ${ }^{1}$, Suikinai N. Santos ${ }^{1}$, \\ Marcia R. Assalin ${ }^{1}$, Tiago D. Zucchi ${ }^{2}$ and Sonia C. N. Queiroz \\ ${ }^{1}$ Embrapa Meio Ambiente, Rod. SP 340, km 127,5, 13820-000 Jaguariúna, São Paulo, Brazil. \\ ${ }^{2}$ Agrivale, Av.Tranquilo Giannini, 1050, 13329-000 Salto, São Paulo, Brazil.
}

Authors' contributions

This work was carried out in collaboration between all authors. Authors ISM, SCNQ and SNS designed the study, performed the statistical analysis, wrote the protocol, wrote the first draft of the manuscript and managed literature searches. Authors WRS and LJS performed and author TDZ

managed in vitro assay and enzymatic analysis, also too, molecular identification. Author MRA performed spectrometric analysis of the study. All authors read and approved the final manuscript.

Article Information

DOI: 10.9734/BMRJ/2016/25314

Editor(s):

(1) Joao Lucio Azevedo, University of São Paulo, Department of Genetics, Brazil. (2) Laleh Naraghi, Plant Disease Research Department, Iranian Research Institute of Plant Protection, Tehran, Iran.

(3) Alok K. Upadhyay, Fox Chase Cancer Center, Philadelphia, Pennsylvania, USA. Reviewers:

(1) Rylosona Janarthini, Shanghai Jiao Tong University, China. (2) Susu Zughaier, Emory University School of Medicine, USA. Complete Peer review History: http://sciencedomain.org/review-history/14226

Original Research Article

Received $27^{\text {th }}$ February 2016 Accepted $4^{\text {th }}$ April 2016 Published $18^{\text {th }}$ April 2016

\section{ABSTRACT}

Aims: Epiphytic bacteria, isolated from Deschampsia antarctica, were screened for their potential to inhibit the plant pathogen Botrytis cinerea, the causal agent of gray mold disease of strawberry pseudofruits. This phytopathogenic fungus is more active and the disease is more serious in temperate climate where the temperatures are lower.

Methodology: The approach involved the isolation and characterization of bacteria from the phyllosphere of $D$. antarctica and the evaluation of their antifungal activity.

Results: A total of 56 bacterial strains were isolated and only one of them, identified by the sequencing of $16 \mathrm{~S}$ rDNA gene, as Pseudomonas frederiksbergensis CMAA 1323, inhibited the mycelial growth and the conidial germination of the fungus. Its ethyl acetate extract also inhibited 
the mycelial growth. Analysis of the bioactive fraction by using liquid chromatography coupled to a mass spectrometry (LC-MS) revealed the presence of cyclo(Pro-Val), a compound belonging to the class of diketopiperazines (DKPs).

Conclusion: These findings support the potential use of the psychrophilic bacterium $P$. frederiksbergensis as promising antifungal agent, and highlight the need for more studies with this bacterium in the biological control of plant pathogenic fungi.

Keywords: Psychrophilic bacteria; Pseudomonas frederiksbergensis; bioactive compounds; Botrytis cinerea; diketopiperazines.

\section{INTRODUCTION}

Bacteria dominate most Antarctic ecosystems. In this extremely cold environment, bacteria have colonized various habitats and have evolved a number of strategies for coping with the extreme physico-chemical fluctuations to which they are exposed. They play key roles in ecology and have potential uses in low-temperature biotechnological processes. In particular, antagonistic activity may contribute to the adaptation of Antarctic bacteria by reducing the presence of competitive microorganisms. However, little is known about the diversity of these microorganisms. Some reports indicated that there are substantial members of novel bacteria with antimicrobial activities in Antarctica. Antifungal activity was found in Antarctic bacteria. Some of them exhibited strong antimycotic activity against Candida albicans [1]. Pseudomonas and Pedobacter, isolated from soil sample of Antarctica were found to inhibit the growth of foodborne pathogens [2]. The use of psychrophilic microorganisms to control phytopathogenic fungi in low temperatures has thus far been very limited. The postharvest decay of fruits and vegetables, caused by Botrytis cinerea is a major global challenge. Although it is difficult to determine the full extent of postharvest losses due to diseases, conservative estimates indicate that $20-25 \%$ of the harvested fruits and vegetables are decayed by pathogen during postharvest handling [3-6]. Fungicides are a primary means of controlling postharvest diseases. Public and scientific concerns about the presence of synthetic chemicals in our food supply and in the environment have been increasing over the last decade. Biological control, and natural fungicides present an attractive option, and the use of microorganisms for the control of plant disease has shown potential as an alternative to synthetic fungicides for the control of post-harvest diseases [7]. The use of secondary metabolites, produced by microbial agents, has attracted interest due to their natural properties.
Among bacteria, a number of Gram-positive and Gram-negative bacteria have been evaluated as biological control agents (BCAs). Several strains of the genus Bacillus and Pseudomonas have received significant attention as BCAs [8-10]. Some microbial agents have reduced the amount of decay caused by Botrytis cinerea in strawberries were reported [11-15] as effective BCAs against diseases of different fruits and produce various antibiotics with antifungal activity including phenazine-1-carboxilic acid, pyoluteorin, pyrrolnitrin, and 2,4diacetylphloroglucinol [16].

Strawberry fruits have a very short post-harvest life due, in part, to gray mold caused by Botrytis cinerea [17]. Infection is more selective in moderate temperatures and even in low temperatures when develop abundantly. The control of gray mold depends on the fungicides, the efficacy of which is frequently decreased by the development of resistant strains of pathogens. Biological control in the postharvest environment has significant advantages over that under field conditions because the two most important factors affecting biocontrol, temperature and relative humidity, are constant and under strict control.

Therefore, this strategy may constitute an important alternative for control. Bacteria, and in particular the psychrophiles from Antarctica, have been found to produce a wide variety of compounds with medical importance (such as antibiotics) as well as many unique enzymes that are active at low temperatures [18]. Thus, the objective of this study was to select effective psychrophilic bacteria associated to the leaf surfaces of Deschampsia antarctica, one of only two native flowering plants occurring throughout maritime Antarctica with antagonistic properties against Botrytis cinerea, a plant pathogenic fungus that is common in temperate climates. The plant, with its adaptation to the cold environments of Antarctica, has attracted the interest of many researchers for genes associated with freezing tolerance. 


\section{MATERIALS AND METHODS}

\subsection{Isolation of Epiphytic Bacteria from Deschampsia antarctica}

Specimens of Deschampsia antarctica Desv. (Poaceae) (Fig. 1) were collected in the Antarctic Specially Managed Area (ASMA) in Admiralty Bay, King George Island, Antarctica (6209 S, $5828 \mathrm{~W})$. This gramineae is a highly freezetolerant plant.

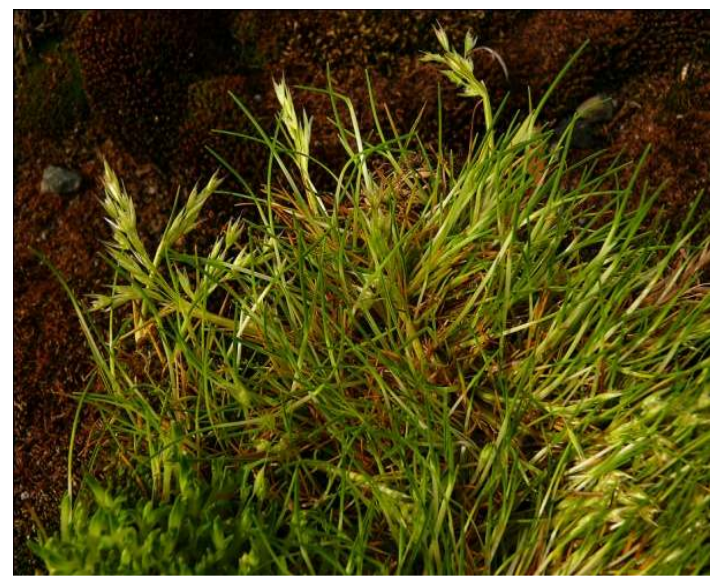

Fig. 1. A view of $D$. antarctica, the only monocotyledonous species that is adapted

to the harsh environmental conditions, occurring throughout Maritime Antarctica. Details of the fine leaved hair grass showing flowers that are self-pollinating (Photo by I. S. Melo, 2010)

Fresh leaves of Deschampsia antarctica were collected aseptically from plants growing under natural conditions during the austral summer (between January and February of 2010), and placed in sterile plastic bags. The samples were taken to the laboratory at the Brazilian Antarctic Station "Comadante Ferraz". A total of $10 \mathrm{~g}$ of leaves were suspended in isotonic $\mathrm{NaCl}$ solution, and serial dilutions were plated on TSA (Tryptic Soy Agar) medium. The plates were incubated at $1^{\circ} \mathrm{C}$ for seven days, and morphologically distinct colonies were purified, and evaluated for their antagonistic activity against the pathogenic fungus Botrytis cinerea. All strains were cryopreserved at $-80^{\circ} \mathrm{C}$ and deposited in the Culture Collection of Microorganisms of Environmental and Agricultural Importance (CMAA) of Brazilian Agricultural Research Corporation (EMBRAPA), located in Jaguariúna, São Paulo, Brazil.

\subsection{Pathogen Inoculums}

Botrytis cinerea CCMA 1122 strain, obtained from the Culture Collection of Microorganisms of Agricultural and Environmental Importance (CCMA), was used throughout the assays. This strain was originally isolated from rotted strawberry pseudofruits with typical symptoms of gray mold.

\subsection{Antagonistic Activity in vitro}

The assay for antagonism was performed by the dual culture method. Mycelial plugs $(7 \mathrm{~mm}$ diameter) of $B$. cinerea were placed on one side of the Petri dishes containing potato-dextroseagar (PDA) medium. Half of the dishes were incubated at $4^{\circ} \mathrm{C}$ and another half at $18^{\circ} \mathrm{C}$ for 24 hs. A loopful of bacteria was then streaked $6 \mathrm{~cm}$ away from the disc of the pathogen. The cultures were incubated in the two temperatures mentioned above. Dishes inoculated only with the pathogen served as control. The percentage growth inhibition (PGI) was calculated using the formula:

$$
\text { PGI }(\%)=K R-R 1 / K R \times 100 \text {, }
$$

Where KR represents the distance (measured in $\mathrm{mm}$ ) from the point of inoculation to the colony margin on the cornel dishes, and R1 the distance of fungal growth from the point of inoculation to the colony margin on the treated dishes in the direction of the antagonist.

\subsection{Identification of the Bacterium}

The antagonistic bacterium was characterized by 16S rDNA sequencing. Genomic DNA was extracted from the strain using PureLink Genomic DNA kit (Invitrogen) following the manufacturer's protocol. 16S ribosomal RNA (rRNA) gene sequencing was achieved following the method of [19]. The 16S rRNA gene sequences were alignment using MEGA version 5 software [20]. Against corresponding sequences of closely related type strains of Pseudomonas species retrieved from the GenBank database.

\subsection{Extraction of Bioactive Metabolites and Antifungal Assays}

Strain CMAA 1323 was inoculated into $500 \mathrm{~mL}$ Erlenmeyer flasks containing potato dextrose broth and incubated at $18^{\circ} \mathrm{C}$ under agitation 
(128 gx $1 \mathrm{~min}$ ) for 14 days. The culture was filtered and the aqueous phase extracted with ethyl acetate. The organic phase was dried over anhydrous sodium sulfate, filtered and the solvent evaporated in a rotary evaporator. This crude extract was evaluated for antifungal activity against $B$. cinerea using the paper assay disc method as described by [21]. The effects of the crude extract on conidial germination of the fungus were also tested. The fungicide Cercobin was included in the assay as positive control.

\subsection{Bioassay-directed Fractionation for the Identification of Antifungal Compounds}

The ethyl acetate (EtAc) crude extract of the CMAA 1323 strain was subjected to bioassaydirected fractionation. Specifically, $64.5 \mathrm{mg}$ of EtAc extract isolated from the culture medium at $\mathrm{pH} 3.0$ was dissolved in $8.0 \mathrm{~mL} \mathrm{MeOH} / \mathrm{H}_{2} \mathrm{O}$ $(90: 10, \quad \mathrm{v} / \mathrm{v})$ and subjected to liquid/liquid partitioning with hexane $(3 \times 8 \mathrm{~mL})$ to collect the resulting hexane fraction (HexFr). Water $(2.3 \mathrm{~mL})$ was added to the remaining partition $\left(\mathrm{MeOH} / \mathrm{H}_{2} \mathrm{O}, \quad 90: 10, \quad \mathrm{v} / \mathrm{v}\right)$ to yield $70: 30$ $\mathrm{MeOH} /$ water $(\mathrm{v} / \mathrm{v})$. The sample was then partitioned with $24 \mathrm{~mL}$ of chloroform $(3 \times 8 \mathrm{~mL})$ to collect the chloroform fraction $\left(\mathrm{CHCl}_{3} \mathrm{Fr}\right)$. Residual $\mathrm{MeOH}$ was removed by rotary evaporation followed by the addition of ethyl acetate $(3 \times 8 \mathrm{~mL})$ to produce the ethyl acetate fraction (EtOAcFr). The water extract was lyophilized to produce the water fraction (AqFr). The four fractions were then subjected to the antifungal bioassay.

\subsection{The QTOF-MS Analysis of the Bioactive Fraction}

A Quadrupole-time of flight mass spectrometry (QTOF-MS) (Waters, Milford, MA USA) coupled to UPLC, Waters Acquity system (Waters, Milford, MA USA) equipped with a binary solvent delivery system and an autosampler was used. The mobile phase consisted of $(A) 0.1 \%$ formic acid in water and (B) methanol. The isocratic mode was used with $60 \% \mathrm{~B}$ at flow-rate of 200 $\mu \mathrm{L} \min ^{-1}$. Total run time was $2 \mathrm{~min}$ and the injection volume was $2 \mu \mathrm{L}$. The mass spectrometry system was operated in $\mathrm{V}$ mode and it was calibrated routinely in the positive electrospray ionization $(E S I+)$ mode using the solution of sodium formate. For MS experiments, the samples were infused direct into the mass spectrometer by syringe pump at $5 \mu \mathrm{L} \mathrm{min}{ }^{-1}$, with the TOF data being collected between $\mathrm{m} / \mathrm{z} 50$ 1000 with low collision energy. The optimized conditions were desolvation gas flow $500 \mathrm{~L} \mathrm{~h}^{-1}$ at a temperature of $400{ }^{\circ} \mathrm{C}$, cone gas $30 \mathrm{~L} \mathrm{~h}^{-1}$ and source temperature $120^{\circ} \mathrm{C}$, capillary, sample cone and extraction cone voltages 1500, 20 and $5 \mathrm{~V}$ respectively. The MCP detector voltage was $1800 \mathrm{~V}$. For the most abundant $\mathrm{m} / \mathrm{z}$ obtained were performed the MS/MS experiment keeping of the $\mathrm{m} / \mathrm{z}$ of the ion precursor selected in MS experiment. The collision energy was increased from 6 to $25 \mathrm{~V}$ and others conditions were maintained.

\subsection{Chitinolytic Activity of $P$. frederiksbergensis}

Chitinase is an important enzyme produced by certain biological agents capable of lysing the cell wall of pathogenic fungi. The chitinase activity was measured using colloidal chitin azure (Sigma) as a substrate following [22]. The substrate was prepared by incubating $1 \mathrm{~g}$ chitin azure in $25 \mathrm{~mL}$ of $85 \%$ phosphoric acid at room temperature (approximately $20^{\circ} \mathrm{C}$ ) for $24 \mathrm{~h}$ under constant agitation (150 rpm). The chitin azure was collected via centrifugation $\left(10,000 \mathrm{~g} \mathrm{x} 25^{\circ} \mathrm{C}\right.$ $x 10 \mathrm{~min}$ ) and washed with distilled water until $\mathrm{pH}$ neutralization. Each enzymatic reaction contained $400 \mu \mathrm{L}$ of $0.3 \%$ colloidal chitin azure $(\mathrm{w} / \mathrm{v})$ prepared in glycine- $\mathrm{NaOH}$ buffer $(50 \mathrm{mM}$, $\mathrm{pH}$ 9.0) that was incubated with $200 \mu \mathrm{L}$ of the crude enzyme extract. The reaction was interrupted by the addition of $200 \mu \mathrm{L}$ of $2 \mathrm{~N} \mathrm{HCl}$. The samples were then centrifuged $(10,000 \mathrm{~g} \mathrm{x}$ $10 \mathrm{~min}$ ), and the supernatant was collected prior to quantification via spectrophotometry at 550 $\mathrm{nm}$. One unit of enzyme activity (U) was defined as the amount of enzyme required to increase the value of the absorbance of the supernatant in 0.001 spectrophotometer reads per minute. For chitinase molecular weight estimation, Amicon Ultra Centrifugal Filter Devices (30, 50, and 100 $\mathrm{KDa}$ ) for the concentration and purification of biological samples (Millipore, Bedford, PA) were used following the manufacturer's protocol. The bacterium was grown in Glucose Yeast Extract Agar medium supplemented with $1 \%$ colloidal chitin by means of the degradation of this polymer, which was observed through the halo zone. The inoculation of the bacterium in this medium was performed by dropping $3 \mu \mathrm{L}$ of a suspension of $1 \times 10$ at $22{ }^{\circ} \mathrm{C}$ for 7 days. 


\section{RESULTS}

\subsection{Isolation, Identification and Evaluation of the Antifungal Activities of Epiphytic Bacteria}

A total of 56 bacterial isolates were obtained from the leaf surface of $D$. antarctica; all of them grew more densely at $4^{\circ} \mathrm{C}$ and $1^{\circ} \mathrm{C}$ than at $2^{\circ} \mathrm{C}$; this putatively suggests a psychrophilic classification (based on Herbert, 1986) [23]. All isolates were tested against the pathogenic fungus $B$. cinerea at $4^{\circ} \mathrm{C}$ and $18^{\circ} \mathrm{C}$, and only one bacterial strain (CMAA 1323) completely suppressed the mycelia growth of the pathogen in both temperatures (Fig. 2).

The obtained sequence of the 16S rDNA gene showed that the bacterial strain CMAA 1323 belongs to the species Pseudomonas frederiksbergensis (GenBank accession № JAJ287, homology 99.9\%). The phylogenetic tree of the 16S rDNA sequence from the strain CMAA 1323 , which was constructed using the neighborjoining method, is shown in Fig. 3.

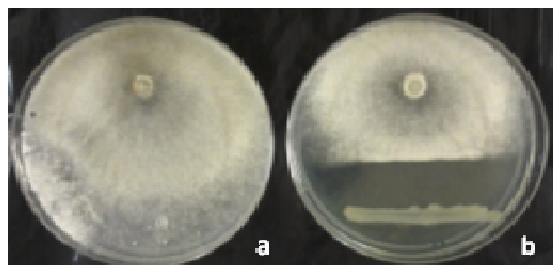

Fig. 2. In vitro inhibition assay: Botrytis cinerea against strain CMAA 1323

\subsection{The in vitro Suppression of the Mycelial Growth and Conidial Germination of $B$. cinerea by Crude Extracts of strain CMAA 1323}

The biological activities of the compounds were evaluated towards $B$. cinerea. Thus, the bioassay with ethyl acetate extract from the fermentation broth of this bacterial strain showed high mycelial inhibitory activity with large inhibitory zones. Both spore germination (Table 1) and the germ tube length of $B$. cinerea were also inhibited by the crude extract of $P$. frederiksbergensis CMAA 1323.

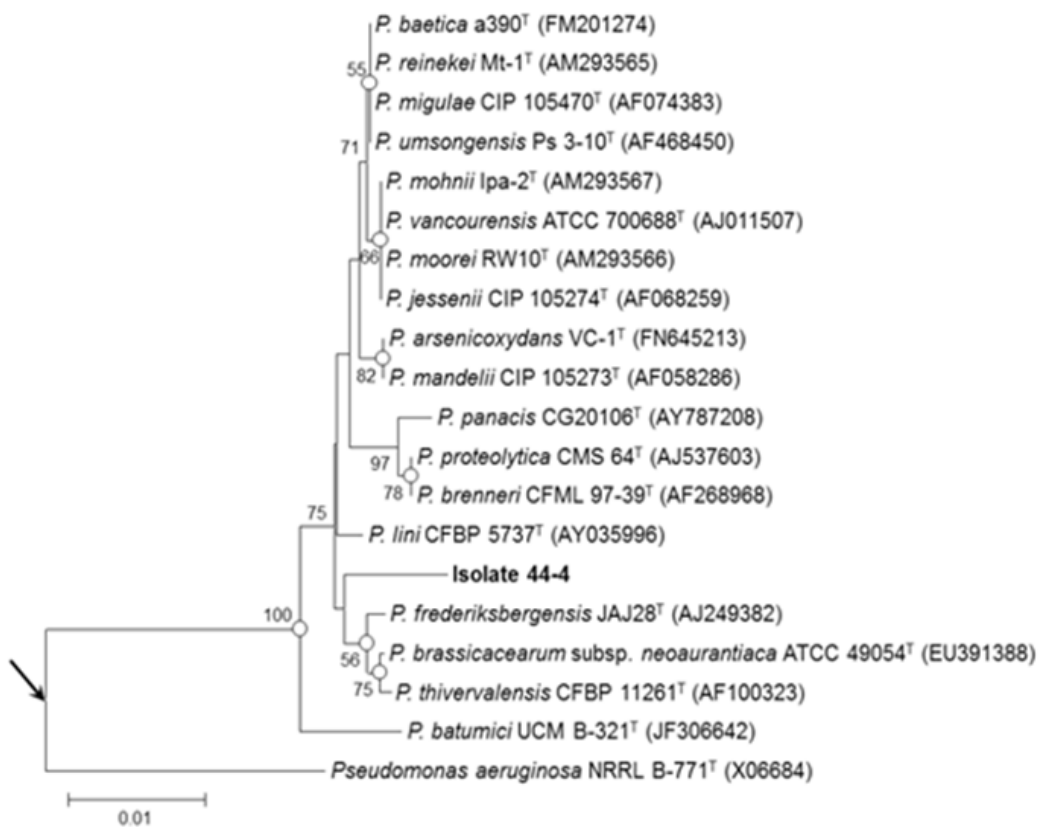

Fig. 3. Neighbour-joining tree based on nearly complete $16 \mathrm{~S}$ rRNA gene sequences ( $1000 \mathrm{bp})$ showing relationships between isolate CMAA 1323 and the type strains of phylogenetically close Pseudomonas species. White circles indicate branches of the tree that were recovered with the maximum-likelihood and maximum-parsimony tree-making algorithms. Numbers at the nodes are percentage bootstrap values based on a neighbor-joining analysis of 1,000 resampled datasets; only values above $50 \%$ are given. Halomonas elongate ATCC $33173^{\top}$ (GenBank accession number M93355) was used as the outgroup. The arrow indicates the inferred root position Bar 0.01 substitutions per nucleotide position 
Table 1. Inhibition of conidial germination of Botrytis cinerea by crude extracts of Pseudomonas frederiksbergensis CMAA 1323

\begin{tabular}{|c|c|c|c|c|c|}
\hline \multicolumn{6}{|c|}{ Conidial germination (\%) } \\
\hline \multirow{2}{*}{$\begin{array}{l}\text { Incubation } \\
\text { period (h) }\end{array}$} & \multirow{2}{*}{ DMSO* } & \multirow{2}{*}{$\begin{array}{l}\text { Cercobin } \\
5.0 \mathrm{mg} \mathrm{mL}^{-1}\end{array}$} & \multicolumn{3}{|c|}{ Crude extract } \\
\hline & & & $5.0 \mathrm{mg} \mathrm{mL}^{-1}$ & $1.0 \mathrm{mg} \mathrm{mL}^{-1}$ & $0.1 \mathrm{mg} \mathrm{mL}^{-1}$ \\
\hline 8 & $87.0 \pm 4.4$ & $75.3 \pm 4.5$ & $97.3 \pm 1.2$ & $33.0 \pm 3.6$ & $82,7 \pm 3,1$ \\
\hline 12 & $49.0 \pm 1.9$ & $63.0 \pm 4.9$ & $94.0 \pm 2.6$ & $87.4 \pm 5.7$ & $56.0 \pm 4.4$ \\
\hline 14 & $19.0 \pm 4.4$ & $15.0 \pm 3.5$ & $95.7 \pm 2.1$ & $73.0 \pm 4.4$ & $33.7 \pm 3.6$ \\
\hline
\end{tabular}

A light microscope investigation revealed that the crude extract from $P$. frederiksbergensis CMAA 1323 caused cellular damages with effects on the conidial germination of $B$. cinerea (data not shown). The results showed that after incubation at $18 \pm 0.5^{\circ} \mathrm{C}$ for $12 \mathrm{~h}$, the percentage of spore germination of $B$. cinerea treated with crude extract $\left(5 \mathrm{mg} \cdot \mathrm{mL}^{-1}\right)$ was $6 \%$, while the percentage of spore germination in the control (the commercial fungicide Cercobin) was $37 \%$. When the concentration of the extracts was decreased to $1 \mathrm{mg}$ and $0.1 \mathrm{mg} \cdot \mathrm{mL}^{-1}$, the effect on spore germination was reduced.

\subsection{Chitinolytic Enzyme and its Effect on the Mycelial Growth of $B$. cinerea}

Pseudomonas frederiksbergensis (strain CMAA 1323) secretes active chitinolytic enzyme to the culture medium, producing hydrolytic zones when applied to water agar containing chitin. The chitinase activity was tested with different parameters such as varying $\mathrm{pH}$ and temperature. The optimal conditions for chitinase activity by Pseudomonas CMAA 1323 were at $15^{\circ} \mathrm{C}$ and with an alkaline $\mathrm{pH}$. The time course of chitinase production is shown in Fig. 4. The highest level of chitinase production occurred on the $5^{\text {th }}$ day of incubation. Growth temperature, particularly for extremophile bacteria, is another critical factor that needs to be studied. In this study, the $P$. frederiksbergensis strain CMAA 1323 produced maximum chitinase activity at $15^{\circ} \mathrm{C}$. At higher temperatures (even $20^{\circ} \mathrm{C}$ ), the enzymatic activity sharply decreased. In vitro assay, Pseudomonas chitinase had the potential for cell wall lysis. The enzyme fraction was inhibitory to the germination of $B$. cinerea (Fig. 5).

\subsection{Identification of the Compounds in the Bioactive Fraction}

An antifungal metabolite was detected in the bioactive fraction of $P$. frederiksbergensis using Liquid Chromatography coupled to a mass spectrometer (LC-MS-Qtof). The mass spectra of the extract gave the data ESI-MS $\mathrm{m} / \mathrm{z} 197.1290$ $[\mathrm{M}+\mathrm{H}]^{+}$and ESI-MS $\mathrm{m} / z 155.0821[\mathrm{M}+\mathrm{H}]^{+}$. The data for the fragments correspond well to those determined by other authors, indicating the presence of cyclo (Pro-Val) (Fig. 6) [24,25].
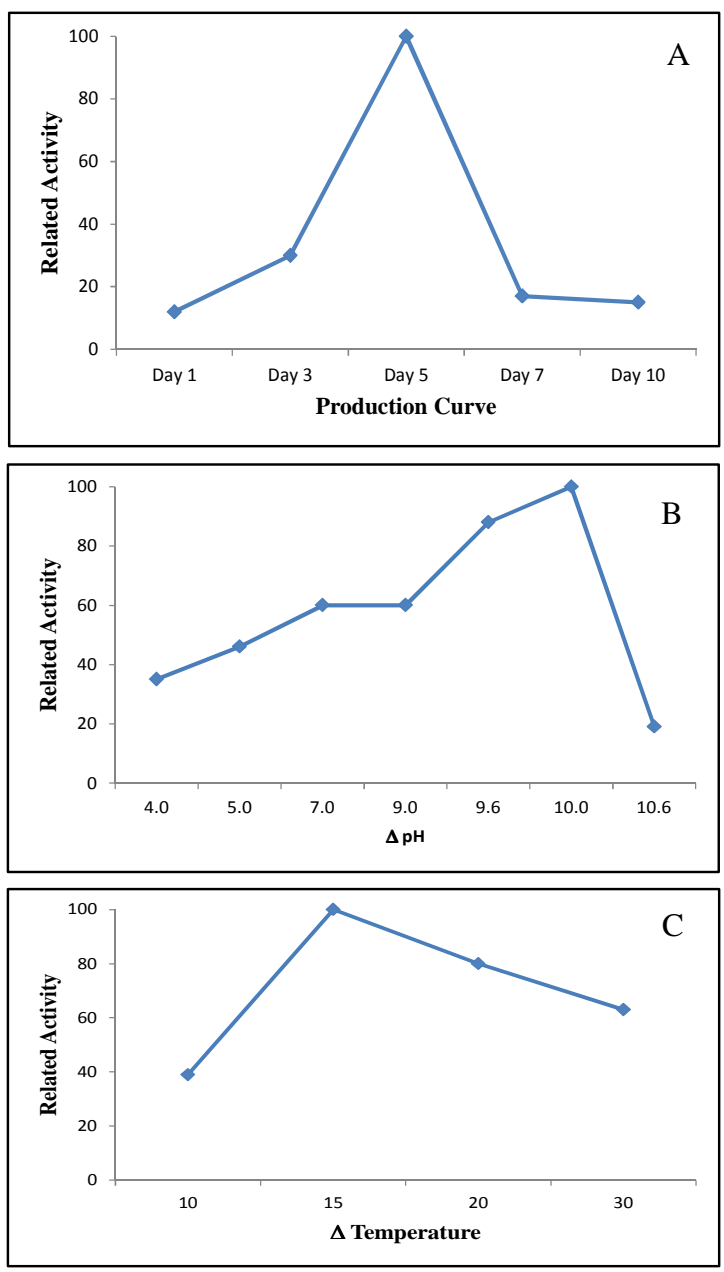

Fig. 4. Effect of chitinolytic enzyme kinetic produced by strain CMAA 1323.

A) Production curve on the complex Chitinolytic; B) Effect of $\mathrm{pH}$ on chitinase production; C) Effect of temperature for chitinase production 


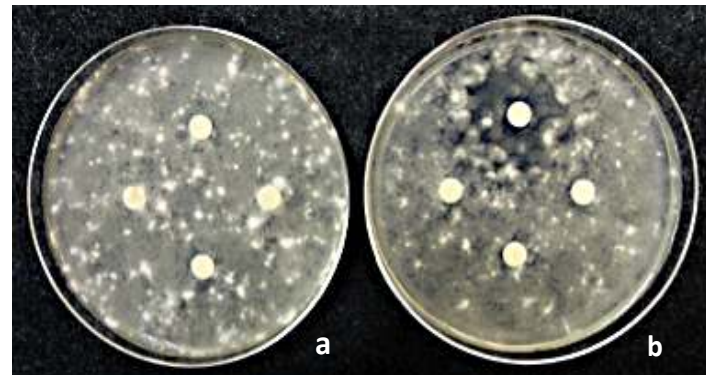

Fig. 5. Effect of the chitinase produced by Pseudomonas frederiksbergensis on the lysis of mycelia of Botrytis cinerea. (a) Control Botrytis cinerea conidia germination,

(b) Assay - Enzymatic activity inhibiting the conidia germination

This compound belongs to the class of diketopiperazines (DKPs), which are cyclic dipeptides formed from the N-terminal amino acid residues of a linear peptide or protein [24]. These compounds are among the smallest peptide derivatives commonly found in nature [26]. Diketopiperazines have been isolated from Gram-negative and Gram-positive bacteria, fungi, and higher marine organisms [27]. DKPs have demonstrated pharmacological activities, most of which inhibit tumor growth, and are used as antihypertensive agents, antibacterial and antifungal substances [28]. Many DKPs have been isolated because of antifungal activities [29]. Cyclo(Pro-Val) was also isolated from Pseudomonas spp. by [30] and showed antifungal activity against Rhizoctonia solani. The marine bacterium Pseudomonas rhizosphaerae, isolated from the deep sea sediments, produced six different DKPs which showed antibacterial activities towards five marine fouling bacteria [31]. Another study revealed DKPs as extracellular signaling molecules produced by different species of Pseudomonas involved in quorum sensing mechanisms [32].<smiles>CC(C)[C@H]1NC(=O)[C@@H]2CCCN2C1=O</smiles>

Fig. 6. Structure of the bioactive compound Cyclo(Pro-Val) produced by $P$. frederiksbergensis

\section{DISCUSSION}

Antarctic bacteria provide an increasing number of biologically active metabolites, and have been recognized as a new source of novel antimicrobial compounds. The present study showed that the plant pathogenic fungus $B$. cinerea can be effectively controlled via Pseudomonas frederiksbergensis CMAA 1323 due to its antagonistic capability to inhibit spore germination and mycelial growth. This study suggests that the isolation of extremophylic microorganisms from the leaf surfaces of a plant growing in Antarctica can assist in controlling postharvest diseases at low temperatures. Further assays in greenhouse conditions need to be done to prove the potential of the bacterium in the biocontrol of the disease. Most pome fruits are stored at cold temperatures. Thus, a microbial antagonist used to control postharvest diseases should have the ability to survive under cold storage conditions. Our experiments suggested that the antifungal property is due to an antifungal complex involving antibiotic metabolites and cell wall-degrading enzymes, such as chitinolytic enzymes, and that this occurs even though other mechanisms may still be operating. Thus, this bacterial strain possesses biological properties that could be used in the field to control $B$. cinerea in low temperature and/or refrigerated chambers [33] indicated that the suppression of $B$. cinerea growth in vitro by selected moderately psychrophilic isolates and the formation of inhibition zones were presumably due to metabolite release from bacteria into the culture medium. Antagonists that compete with the saprophytic growth of Botrytis spp. may reduce pathogen growth and/or sporulation in crop debris, resulting in the reduction of disease progress rate.

Bacterial communities that develop in the phyllosphere are adapted to tolerate high irradiation, strong winds, and low humidity stresses. Few studies have investigated the epiphytic microorganisms that are associated with Antarctic plants. The Antarctic terrestrial biota is periodically exposed to enhanced solar UV-B, and the ecological success of bacteria in UVR-exposed habitats is enabled by the ability of the organisms to effectively repair DNA damage as it is incurred or to avoid the occurrence of DNA damage through the colonization of sites that are shaded from UVR (if available). In these environments, extremophiles, particularly bacteria, thrive in extremely low temperatures. 
According to Sharma et al. [3], a potential microbial antagonist should have certain desirable characteristics. The antagonist should be (a) genetically stable; (b) effective at low concentrations; (c) not fastidious in its nutritional requirements; (d) capable of surviving under adverse environmental conditions; (e) effective against a wide range of pathogens and useful for a variety of harvested commodities; ( $f$ ) nonpathogenic to the host; (i) grown in a form that can be effectively stored and dispensed; and (j) compatible with other chemical and physical treatments. Additionally, a microbial antagonist should have an adaptive advantage over a specific pathogen. The CMAA 1323 strain of $P$. frederiksbergensis is a promising psychrophilic bacteria which has many traits useful in biological control. One of them is the secretion of lytic enzymes that can sometimes result in suppression of plant pathogen activities. Chitin is a polymeric compound that comprises the cell walls of many pathogenic fungi. Thus, the chitinase released by many microorganisms can hydrolyze a wide variety of plant pathogenic fungi. Therefore, the control of Sclerotium rolfsii by Serratia marcescens appeared to be mediated by chitinase expression [34] and b-1,3glucanase contributes significantly to the biocontrol activities of Lysobacter enzymogenes strain C3 [35]. Lysobacter and Myxobacteria are known by the production of copious amounts of lytic enzymes, and some isolates have been shown to be effective at suppressing fungal plant pathogens [36].

The production of antibiotics is another important mechanism by which microbial antagonists suppress pathogens. For instance, bacterial antagonists such as Bacillus subtilis and Pseudomonas cepacia Burkh are known to kill pathogens by producing the antibiotic iturin $[37,38]$. The antagonism of Bacillus subtilis was effective in controlling fungal rot in citrus [39] and Monilinia fructicola in peaches and cherries $[38,40]$. Another bacterium, Pseudomonas cepacia has been studied in the control of some plant diseases. The bacterium inhibited the growth of postharvest pathogens such as Botrytis cinerea and Penicillium expansum in apples by producing the antibiotic pyrrolnitrin $[12,41]$. Similar results were found in this study, but the bioactive compound involved in the inhibition was a diketopiperazine (DKP), which is a cyclic dipeptide formed from the N-terminal amino acid residues of a linear peptide or protein [24]. DKPS are among the most common peptide derivatives found in nature and are commonly biosynthesized from amino acids by different organisms, including mammals [26]. DKPs have demonstrated pharmacological activities, most of which inhibit tumor growth, and are used as antihypertensive agents, or serve as antibacterial and antifungal substances $[28,42]$ demonstrated the antifungal activity against Plasmopara viticola of three DKPs that were extracted from the grapevine endophyte $A$. alternata. Cyclo(Pro-Val) was isolated from Pseudomonas spp. by Park et al. [30] and showed antifungal activity against $R$. solani. Because the compound isolated in this study is already known, as are its antifungal properties, it was not isolated from the extract, which is a complex mixture. Thus, we can suppose that this compound contributes to the antifungal properties of the extract against the fungus Botrytis cinerea.

It is noteworthy that the $P$. syringae strain ESC10 is commercially available (Bio-Save-1000, EcoScience Corporation, Orlando, FL, USA) as a biocontrol agent against molds of citrus caused by $P$. digitatum and Penicillium italicum [13]. The applications of $P$. s. pv. syringae strains reduced postharvest green and blue mold in citrus and apple fruits, respectively [43]. Thus, this study highlights the potential use of Pseudomonas frederiksbergensis CMAA 1323 as an antifungal agent. This is the first report in which psychrophilic bacteria, isolated from the Antarctica have been tested for their antagonistic potential against gray mold. Detailed investigations on epiphytic bacteria colonizing Antarctic plants may provide a unique source to discover prototype molecules for use in biopesticide discovery studies.

\section{CONCLUSION}

These findings support the potential use of the psychrophilic bacterium $P$. frederiksbergensis as promising antifungal agent. However, further investigations are needed to develop this biological control in order to confirm the activity of the isolated compound Cyclo(Pro-Val) against Botrytis cinerea and to evaluate the side effects in beneficial microorganisms, such as those present in gut microbiota.

\section{COMPETING INTERESTS}

Authors have declared that no competing interests exist. 


\section{REFERENCES}

1. Shekh RM, Singh $P$, Singh SM, Roy U. Antifungal activity of Arctic and Antarctic bacteria isolates. Polar Biol. 2011;34: 139-143.

2. Wong C, Tam H, Alias S, González M, González-Rocha G, Domínguez-Yévenes M. Pseudomonas and Pedobacter isolates from King George Island inhibited the growth of foodborne pathogens. Polish Polar Research. 2011;32:1-14.

3. Sharma RR, Singh D, Singh R. Biological control of postharvest diseases of fruits and vegetables by microbial antagonists: A review. Biol Cont. 2009;50:205-221.

4. Droby S. Improving quality and safety of fresh fruits and vegetables after harvest by the use of biocontrol agents and natural materials. Acta Hort. 2006;709:45-51.

5. Zhu SJ. Non-chemical approaches to decay control in postharvest fruit. In: Noureddine B, Norio S, (Eds.). Advances in postharvest technologies for horticultural crops. Research Signpost, Trivandrum, India. 2006;297-313.

6. El-Ghaouth $\mathrm{A}$, Wilson $\mathrm{C}$, Wisniewski $\mathrm{M}$. Biologically-based alternatives to synthetic fungicides for the postharvest diseases of fruit and vegetables. In: Naqvi SAMH (ed) Diseases of fruit and vegetables, Kluwer Academic Publishers, The Netherlands. 2004;II:511-535.

7. Wisniewski ME, Wilson CL. Biological control of postharvest diseases of fruits and vegetables: Recent advances. HortScience. 1992;27:94-98.

8. Leclére V, Béchet $M$, Adam A, Guez JS, Wathelet $B$, Ongena $M$, Thonart $P$, Gancel F, Chollet-Imbert M, Jacques P. Mycosubtilin overproduction by Bacillus subtilis BBG100 enhances the organism's antagonistic and biocontrol activities. Appl. Environ. Microbiol. 2005;71:4577-4584.

9. Chen $\mathrm{XH}$, Koumoutsi A, Scholz R, Schneider K, Vater J, Süssmuth R, Piel J, Borriss R. Genome analysis of Bacillus amyloliquefaciens FZB42 reveals its potential for biocontrol of plant pathogens. J Biotechnol. 2009;140(1-2):27-37.

10. León M, Yaryura PM, Montecchia MS, Hernández Al, Hernández AI, Correa OS, Pucheu NL, Kerber NL, García AF. Antifungal activity of selected indigenous Pseudomonas and Bacillus from the soybean rhizosphere. Int. J. Microbiol. 2009;2009:572049.
11. Peng G, Sutton JC. Evaluation of microorganisms for biocontrol of Botrytis cinerea in strawberry. Canadian Journal of Plant Pathology. 1991;13:247-257.

12. Janisiewicz WJ, Roitman J. Biological control of blue mold and gray mold on apple and pear with Pseudomonas cepacia. Phytopathology. 1988;78:16971700.

13. Janisiewicz WJ, Jeffers SN. Efficacy of commercial formulations of two biofungicides for control of blue mold and gray mold of apples in cold storage. Crop Protection. 1997;16:629-633.

14. Nunes C, Teixidó N, Usall J, Vinas I. Biological Control of Major Postharvest Diseases on Pear Fruits with Antagonistic Bacterium Pantoea agglomerans (CPA-2). Acta Horticult. 2001;553:403-406.

15. Meziane H, Gavriel S, Ismailov Z, Chet I, Chernin L, Höfte M. Control of green and blue mould on orange fruit by Serratia plymuthica strains IC14 and IC1270 and putative modes of action. Post Biol. Technol. 2006;39:125-133.

16. Raaijmakers JM, Weller DM, Thomashow LS. Frequency of antibiotic producing Pseudomonas spp. in natural environments. Appl. Environ. Microbiol. 1997;63:881-887.

17. Wszelaki AL, Mitcham EJ. Effect of combinations of hot water dips, biological control and controlled atmospheres for control of gray mold on harvested strawberries. Post Biol. Technol. 2003;27: 255-264.

18. Michaud L, Di Cello F, Brilli M, Fani R, Lo Giudice A, Bruni V. Biodiversity of cultivable psychrotrophic marine bacteria isolated from Terra Nova Bay (Ross Sea, Antarctica). FEMS Microb Letts. 2004; 230:63-71.

19. Zucchi TD, Almeida LG, Cônsoli FL . Culturable bacterial diversity associated with cysts of Eurhizococcus brasiliensis (Hempel) (Hemiptera: Margarodidae). World. J Microb. Biotech. 2011;27:791797.

20. Tamura K, Peterson D, Peterson N, Stecher G, Nei M, Kumar S. MEGA 5: molecular evolutionary genetics analysis using maximum likelihood, evolutionary distance, and maximum parsimony methods. Mol. Biol. Evol. 2011;28:27312739.

21. Rodrigues E, Supriya T, Naik CG. Antimicrobial activity of marine organisms 
collected off the coast of South East India. J Exp Mar Biol Ecol. 2004;309:121-127.

22. Ramirez MG, Avelizapa LIR, Avelizapa NGR, Camarillo RC. Colloidal chitin stained with Remazol Brilliant Blue R, a useful substrate to select chitinolytic microorganisms and to evaluate chitinases. J. Microb. Methods. 2004;56: 213-219.

23. Herbert RA. The ecology of psychrophilic microorganisms. In: Microbes in extreme environments. Special publication of the society for general microbiology (Ed. by Herbert RA, Codd GA), Academic Press, London. 1986;1-23.

24. Chen YH, Liou SE, Chen CC. Two-step mass spectrometric approach for the identification of diketopiperazines in chicken essence. Eur Food Res Technol. 2004;218:589-597.

25. Ginz M, Engelhardt UH. Identification of new diketopiperazines in roasted coffee. Eur Food Res Technol. 2001;213:8-11.

26. Prasad C. Bioactive cyclic dipeptides. Peptides. 1995;16:151-164.

27. Huang $R$, Zhou $X, X u T$, Yang $X$, Liu Y. Diketopiperazines from marine organisms. Chem Biodivers. 2010;7:2809-2829.

28. McCleland K, Milne PJ, Lucieto FR, Frost C, Brauns SC, Van De Venter M, Du Plessis J, Dyason K. An investigation into the biological activity of the selected histidine-containing diketopiperazines cyclo(His-Phe) and cyclo(His-Tyr). J. Pharm. Pharmacol. 2004;56:1143-1153.

29. Fusetani N. Antifungal peptides in marine invertebrates. Invertebrate Surviv J. 2010; 7:53-66.

30. Park KG, Lim JH, Kim SD, Shim SH. Elucidation of antifungal metabolites produced by Pseudomonas aurantiaca IB5-10 with broad-spectrum antifungal activity. J. Microbiol. Biotechnol. 2012;22: 326-330.

31. Qi SH, Xu Y, Gao J, Qian PY, Zhang S. Antibacterial and antilarval compounds from marine bacterium Pseudomonas rhizosphaerae. Annal Microb. 2009;59: 229-233.

32. Holden MT, Chhabra SR, de Nys R, Stead P, Bainton NJ, Hill PJ, Manefield M, Kumar N, Labatte M, England D, Rice S, Givskov M, Salmond GP, Stewart GS, Bycroft BW, Kjelleberg S, Williams P. Quorum-sensing cross talk: Isolation and chemical characterization of cyclic dipeptides from Pseudomonas aeruginosa and other gram-negative bacteria. Mol. Microbiol. 1999; 33:1254-1266.

33. Essghaier B, Fardeau ML, Cayol JL, Hajlaoui MR, Boudabous A, Jijakli $\mathrm{H}$, Sadfi-Zouaoui N Biological control of grey mould in strawberry fruits by halophilic bacteria. J. Appl. Microbiol. 2009;106:833846.

34. Ordentlich A, Elad Y, Chet I. The role of chitinase of Serratia marcescens in biocontrol of Sclerotium rolfsii. Phytopathology. 1988;78:84-88.

35. Palumbo JD, Yuen GY, Jochum CC, Tatum K, Kobayashi DY. Mutagenesis of 1-3-glucanase genes in Lysobacter enzymogenes strain $\mathrm{C} 3$ results in reduced biological control activity towards Bipolaris leaf spot of tall fescue and Pythium damping off sugarbeet. Phytopathology. 2005;95:701-707.

36. Bull CT, Shetty KG, Subbarao KV. Interactions between myxobacteria, plant pathogenic fungi and biocontrol agents. Plant Dis. 2002;86:889-896.

37. Gueldner RC, Reilly CC, Pusey PL, Costello CE, Arrendale RF, Cox RH, Himmelsbach DS, Crumley FG, Cutler HG. Isolation and identification of iturins as antifungal peptides in biological control of peach brown rot with Bacillus subtilis. J. Agric. Food Chem. 1988;36:366-370.

38. Pusey PL, Wilson CL. Postharvest biological controls of stone fruit brown rot by Bacillus subtilis. Plant Disease. 1984; 68:753-756.

39. Singh V, Deverall BJ. Bacillus subtilis as a control against fungal pathogens of citrus fruit. Trans. Br. Mycol. Soc. 1984;83:487490.

40. Utkhede RS, Sholberg PL. In vitro inhibition of plant pathogens by Bacillus subtilis and Enterobacter aerogenes and in vivo control of two postharvest cherry diseases. Can. J. Microbiol. 1986;32:963967.

41. Janisiewicz WJ. Biological control of postharvest fruit diseases. In: Handbook of applied mycology: Soil and plants (Ed. by Arora DK, Rai B, Mukerji KG, Knudsen GR). Marcel Dekker, New York. 1991;1: 301-326.

42. Musetti R, Polizzotto R, Vecchione A, Borselli S, Zulini L, D’Ambrosio M, di Toppi LS, Pertot I. Antifungal activity of diketopiperazines extracted from Alternaria alternata against Plasmopara viticola: 
An ultrastructural study. Micron. 2007;38: 643-650.

43. Cirvilleri G, Bonaccorsi A, Scuderi G, Scortichini M. Potential biological control

activity and genetic diversity of Pseudomonas syringae pv. syringae strains. J. Phytopathology. 2005;153:654666.

(c) 2016 Melo et al.; This is an Open Access article distributed under the terms of the Creative Commons Attribution License (http://creativecommons.org/licenses/by/4.0), which permits unrestricted use, distribution, and reproduction in any medium, provided the original work is properly cited.

Peer-review history:

The peer review history for this paper can be accessed here: http://sciencedomain.org/review-history/14226 